\title{
Dimensi Ontologis-Etis Konsepsi Ketuhanan Islam: Analisis Hermeneutika Sintetis-Logis Fazlur Rahman dan al-Ṭabāṭabā'ī
}

\author{
Amrizal \\ Sekolah Tinggi Filsafat Islam Sadra \\ av.amrizal@gmail.com
}

\begin{abstract}
As as muslim, it is important to clear up the view of the Godness in Islam which is often misunderstood by some people. Its urgency not only as an enlightment for nonmuslim on Islam, moreover to some of muslim community today. One of those is the accusation which the conception of God in Islam is arbitrarily, cruel, desire to worshipped, requires to defensed brutally, etc. Fazlur Rahman has tried to answer this accusation using Synthetic-Logical Hermenenutics by describing three important conceptions about God in al-Qur'an, namely: the dependency of everything to God, the mercy of God, and the necessary relation between God and human. However, Fazlur Rahman elaborated Moral-Ethical aspect only, minus ontological aspect which is precisely important to answer the accusation above. This minus can be very well covered by 'Allamah al-Tabātabā' '̄'s Tafsìr. By the synthesis of both, the accusation is not only indisputable, but will provide a profound explanation on Godness in Islam. So, then it will appear that the conception of God in Islam not only has a dimension of theological-ethic but firmly philosophical-theoritic.
\end{abstract}

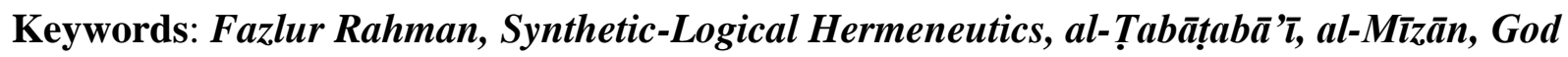

\begin{abstract}
Abstrak: Sebagai muslim, penting untuk menjernihkan pandangan mengenai ketuhanan dalam Islam yang acapkali disalahpahami oleh sebagian orang. Ini penting tidak hanya sebagai pencerahan bagi nonmuslim mengenai Islam, bahkan juga bagi sebagian kalangan muslim saat ini. Di antara kesalahpahaman ini adalah pandangan bahwasanya konsepsi Tuhan dalam Islam bersifat semenamena, kejam, haus akan peyembahan dari hamba, memerlukan pembelaan, dan sejenisnya. Fazlur Rahman telah berupaya menjernihkan kesalahpahaman ini menggunakan Hermeneutika SintetisLogis dengan menjabarkan tiga konsepsi penting mengenai ketuhanan dalam al-Qur'an, yakni: ketergantungan segala sesuatu kepada Tuhan, Tuhan adalah Maha Pengasih, dan keniscayaan akan relasi Tuhan-manusia. Tapi Fazlur Rahman hanya menyentuh aspek Moral-Etis dan kurang menyentuh aspek ontologis yang justru penting untuk menjawab tudingan di atas. Kekurangan ini dapat tertutupi sangat baik dengan tafsir yang disusun oleh 'Allāmah Al-Tabāțabā' ’̄. Dengan sintesa terhadap keduanya tudingan tersebut tidak hanya sekedar terbantahkan, tetapi juga akan memberikan penjelasan konsepsi ketuhanan dalam Islam secara utuh. Sehingga akan tampak bahwa konsepsi ketuhanan dalam Islam tidak sekedar berdimensi teologis-praktis, melainkan memiliki landasan filosofis-teoritis yang kokoh.
\end{abstract}

Kata Kunci: Fazlur Rahman, Hermeneutika Sintetis-Logis, Al-Ṭabātabā’̄, al-Mīzān, Tuhan 


\section{Pendahuluan}

Islam adalah salah satu agama dengan peng-anut yang sangat besar di dunia saat ini. Menurut Pew Research Centre yang dikutip oleh The Guardian, populasinya saat ini berkisar pada angka 1,8 milyar jiwa yang berarti $24 \%$ populasi dunia. Runut posisinya berada di tempat kedua setelah Kristen dengan populasi 2,3 milyar. Tapi seiring pertumbuhan penduduk dunia antara tahun 2015-2060 yang diperkirakan akan men-capai angka 32\%, diproyeksikan Islam akan men-jadi agama dengan pertumbuhan paling cepat dengan tingkat pertumbuhan $70 \%$ sementara Kristen berada di angka 32\%. ${ }^{1}$ Sekalipun tingkat pertumbuhan ini lebih banyak dipengaruhi oleh faktor kelahiran-kematian ketimbang konversi, akan tetapi angka-angka seperti ini tentu menarik bagi siapapun yang memperhatikan berbagai isu mengenai Islam. Belum lagi ditambah bahwa-sanya banyak di antara faktor konversi kepada Islamkhususnya di Dunia Barat-saat ini justru diawali dengan berbagai isu politik yang berkaitan dengan Dunia Islam sehingga memicu rasa ingin tahu.

Seiring dengan fenomena ini, muncul feno-mena lanjutan di mana pusat-pusat pengkajian Islam tumbuh di berbagai belahan dunia. Baik berada di bawah naungan pusat pendidikan ataupun lembaga masyarakat. Termasuk di antaranya adalah tulisan-tulisan yang mengkaji Islam baik dalam bentuk buku, jurnal, atau artikel. Sayangnya pertumbuhan pengkajian Islam, khususnya di Dunia Barat tidak selalu berdampak baik bagi Islam. Banyak pusat-pusat pengkajian Islam di Dunia Barat yang telah me-lahirkan sejumlah orientalis besar dengan semangat akademis

${ }^{1}$ https://www.theguardian.com/news/2018/aug/27/re ligion-why-is-faith-growing-and-what-happens-next. $\mathrm{Di}$ akses pada tanggal 16 September 2019 pukul 23:59 WIB. yang tinggi, seperti Nöldeke-Schwally, Rudi Paret, H. Grimme, Kenneth Cragg, Thomas O'Shaughnessy, Toshihiko Izutsu, AnneMarie Schimmel, dan lain-lain. Karya-karya mereka perlu dibaca dan diapresiasi. Tetapi ada juga sejumlah orientalis seperti John Wansbrough, John Burton, Ignaz Goldziher, dan sejenisnya yang hingga pada batas tertentu karya-karya mereka perlu dikritisi. Tujuannya pun bisa beragam, mulai dari misionaris seperti yang dila-kukan oleh Ron Rhodes hingga politis seperti Snouck Hurgronje-sebagai contoh fenomenal. Ternyata fenomena seperti yang terakhir ini, di Dunia Islam pun ada dan pelakunya pun lahir dari komunitas Islam juga. $^{2}$

Di antara isu sentral yang dipersoalkan adalah mengenai konsepsi ketuhanan dalam Islam. Ringkasnya, Tuhan dalam Islam digambarkan sebagai sosok yang semena-mena, kejam, haus akan penyembahan dari hamba, memerlukan pembelaan, dan sejenisnya. Tentu semua ini tidak bisa dibenarkan.

Tulisan ini akan membahas mengenai konsepsi ketuhanan dalam Islam dengan merujuk kepada Fazlur Rahman dan `Allāmah al-Ṭabātabā'î. Fazlur Rahman dipilih karena ia terdidik di Dunia Barat dan menggagas pendekatan baru dalam memahami al-Qur'an menggu-nakan Hermeneutika yang disusunnya sendiri. Hermeneutika berawal dari filsafat penafsiran dan acapkali diperhadapkan dengan metodologi Tafsir alQur'an apabila digunakan untuk mema-hami al-Qur'an. Adapun 'Allāmah al-Ṭabāțabā'̄̄ jelas karena ia terdidik di Dunia Islam dan terbukti memiliki otoritas dalam kedua disiplin-ilmu-ilmu al-Qur'an dan Filsafat. Kedua disiplin ini menjadi penting dalam

\footnotetext{
${ }^{2}$ Sampai dengan jurnal ini ditulis, penulis memiliki sejumlah referensi untuk ini. Sengaja tidak ditampilkan untuk meringkas pembahasan dan lainnya.
} 
meres-pon tudingan yang disebutkan sebelumnya karena dua hal, yakni: Pertama, al-Qur'an adalah rujukan utama umat Islam sehingga jawaban yang diberikan yang bersumber langsung kepada al-Qur'an akan lebih konkret menjawab tudingan; Kedua, untuk menunjukkan arti penting Filsafat dalam mem-bangun landasan filosofis dikarenakan penerima-an kajian Filsafat di Dunia Islam tidak semulus keilmuan yang lain sehingga berdampak kegaga-pan umat Islam dalam merespon sejumlah isu penting kekinian.

Ruang lingkup kajian meliputi penerapan Hermeneutika Sintetis-Logis oleh Fazlur Rahman terhadap sejumlah ayat al-Qur'an dengan didahu-lui penjelasan mengenainya, disusul tafsir yang disampaikan oleh `Allāmah al-Ṭabātabā'̄̄ atas ayat-ayat yang digunakan oleh Fazlur Rahman dengan didahului penjelasan Tafsīr al-Mīzān yang beliau susun, kemudian menjelaskan titik temu dan sintesis dari keduanya.

Sebagai sintesis dari kedua tokoh besar ini, diharapkan bisa ditemukan suatu penjelasan Qurani yang tidak sekedar mampu merespon tudingan di atas melainkan juga memberikan pencerahan untuk mengantisipasi isu-isu terkait.

\section{Pemahaman Qurani tentang Tuhan}

\section{Berdasarkan Hermeneutika Sintetis-Logis}

1. Keniscayaan Hermeneutika Sintetis-

\section{Logis terhadap Pemahaman Metafisis} al-Qur'an Menurut Fazlur Rahman

Fazlur Rahman adalah salah satu nama yang tidak bisa dilewatkan dalam Kajian Keislaman kontemporer. Latar belakang pendidikannya ber-akar sangat kuat dalam

3 Fazlur Rahman, Islam \& Modernity: Transformation of an Intellectual Tradition (Chicago: The University of Chicago Press, 1982), 2. tradisi pendidikan Islami yang diperoleh semasa di Pakistan dan semakin berkembang setelah menyelesaikan jenjang aka-demis di Inggris. sehingga meng-hadirkan nuansa tersendiri dalam Kajian Keislaman. Dalam kajian penafsiran al-Qur'an ia menghadirkan satu meto-dologi baru dalam upaya memahami al-Qur'an berbasis Hermeneutika. Dia berupaya mengga-bungkan prinsip dan metodologi Tafsir al-Qur'an dengan Hermeneutika. Tujuan dasarnya untuk mengurangi bias mufassir dalam menafsirkan ayat-ayat al-Qur'an.

Walau tidak menafikan sepenuhnya berbagai keberhasilan yang dihasilkan oleh para mufassir dalam upaya mereka memberikan pemahaman al-Qur'an kepada ummat, tetap saja menurut Fazlur Rahman ada berbagai hal yang tidak memuaskan. Hal ini menurutnya dikarenakan metode yang tidak memadai dalam memahami al-Qur'an. Kesalahan umum yang sering tejadi adalah kegaga-lan dalam memahami kesatuan pesan al-Qur'an. Hal ini diperparah dengan adanya desakan tertentu untuk menggiring ayat-ayat al-Qur'an dalam bentuk-bentuk praktis tertentu. Pendekatan atomistik ${ }^{3}$ seperti ini kemudian menghasilkan suatu pemahaman yang tidak seutuhnya sesuai dengan maksud pesan dari ayat-ayat al-Qur'an tersebut. Dampaknya kembali kepada masing-masing bidang kajian dari ayat tersebut.

'Karena kegagalan memahami al-Qur'an sebagai kesatuan mendalam akan mempengaruhi pandangan dunia (weltanschauung) tertentu, harga termahal dibayarkan dalam ranah pemiki-ran teologis. Sedangkan dalam bidang hukum, kecenderungan ketiadaan kesatuan yang 
demiki-an terdapat secara internal, penggabungan materi-materi asing yang telah memperkenalkan sebuah tingkat kepraktisan yang memadai, proses meng-adopsi ide-ide asing yang sama dalam ranah teologi-sekali lagi, dalam ketiadaan sebuah visi kesatuan pandangan dunia (weltanschauung) yang demikian, terbukti mendatangkan malapetaka, setidaknya dalam kasus Asy`arisme, teo-logi Sunni yang dominan sepanjang abad per-tengahan Islam. Ketika pada abad ke-12, sistem teologis Sunni ini bertabrakan dengan metafisika rasional-filosofis para filsuf muslim (yang mem-bangun sistem pemikiran mereka atas dasar Filsafat Yunani, dengan melakukan upaya serius untuk mengakomodasi ortodoksi Islam), kelom-pok pertama hampir menghancurkan kelompok kedua berdasarkan pertimbangannya belaka. Ke-mudian filsafat berlindung dan berkembang da-lam lingkungan intelektual-spiritual Syi ah atau bertransformasi ke dalam Sufisme intelektual." 4

Sekalipun demikian, Fazlur Rahman tidak begitu saja menerapkan Hermeneutika sebagai-mana yang diterapkan oleh para Hermeneut Barat dalam upayanya memahami al-Qur'an. Dia sangat berhati-hati agar tidak terjebak pada pan-dangan orientalis atau intelektual muslim yang terpengaruh dengan kajian orientalis dalam me-mahami al-Qur'an. Dia membangun pandangan-nya sendiri mengenai Hermeneutika dalam ke-rangka pembaharuan terhadap metodologi Tafsir alQur'an. Dia memulainya dengan menyusun kerangka epistemologi Qurani dengan asumsi dasar bahwa-sebagai sumber utama ajaran Islam-al-Qur'an diwahyukan untuk petunjuk bagi manusia, sehingga ia tidak hanya bersifat

\footnotetext{
${ }^{4}$ Fazlur Rahman, Islam \& Modernity, 3.
}

dogmatis melainkan juga sebagai kerangka analitis dan kritis terhadap berbagai hal.

Itulah sebabnya Fazlur Rahman tidak pernah mendefinisikan Hermeneutika yang dibangunnya kepada salah satu jenis Hermeneutika tertentu. Hal ini dikarenakan, di satu sisi ia berangkat dari upaya untuk melakukan pembaharuan terhadap metodologi Tafsir al-Qur'an yang telah mapan di Dunia Islam, sementara di sisi lain ia menghadir-kan suatu jenis Hermeneutika baru dalam filsafat penafsiran. Sehingga lahirlah Pendekatan Sosio-Historis dan Gerak Ganda. Setidaknya ada tiga karakteristik penting dalam kedua bangunan Hermeneutika ini, yakni: ${ }^{5}$

- Perhatiannya terhadap latar belakang dan konteks historis, yang notabene tak lepas dari asbāb al-nuzūl dalam metodologi Tafsir al-Qur'an.

- Penekanan pada pentingnya memahami al-Qur'an sebagai satu kesatuan utuh, yang merupakan kritik dan perhatian utamanya sejak awal.

- Pemerian antara hukum umum dan khusus.

Permasalahan kemudian muncul, ketiga karakteristik ini tentu tidak bisa diterapkan untuk memahami tema-tema Metafisika. Tema-tema seperti kenabian, wahyu, eskatologi, setan, jin, dan sejenisnyatermasuk mengenai tema yang dibahas dalam tulisan ini mengenai Tuhan - tentu melampaui karakter pertama dan ketiga. Tema-tema metafisis seperti ini tidak bisa dikungkung dalam kerangka ruang dan waktu kesejarahan atau aspek legal-formal tertentu. Karenanya dibutuhkan suatu metode yang lebih sesuai selain Pendekatan Sosio-Historis dan Gerak

5 Syamruddin, "Hermeneutika Fazlur Rahman: Upaya Membangun Harmoni Teologi, Etika, dan Hukum" dalam MIQOT, Vol. XXXV No. 2 (2011), 281. 
Ganda. Fazlur Rahman sangat menyadari hal ini.

"Untuk pernyataan-pernyataan teologis dan metafisis al-Qur'an, tidak meniscayakan latar berlakang pewahyuan, sebagaimana juga halnya dengan keputusan sosial-legal, tidak juga penafsir selalu memberikannya, tapi tentu tanpa sebuah kajian sistematis pandangandunia Qurani tidak bisa timbul."”

Maka diperlukan suatu metodologi baru, yakni Sintetis-Logis. Metode Sintetis-Logis adalah pendekatan yang membahas suatu tema dengan cara mengevaluasi ayat-ayat yang berhubungan dengan tema yang dibahas atau tema-tema relevan dengan tema yang dibahas. ${ }^{7}$ Teknis-nya dengan mengumpulkan ayat-ayat dari satu tema, kemudian dievaluasi lalu dibandingkan dengan ayat-ayat dari tema-tema yang berkaitan dan relevan dengannya. Misalnya, saat mem-bicarakan mengenai Tuhan (Khāliq), maka seluruh ayat-ayat mengenainya dikumpulkan, kemudian dievaluasi untuk dibandingkan dengan ayatayat yang berkenaan dengan ciptaan (makhlūq). Jelas ada suatu keterkaitan logis di antara kedua tema tersebut. Kemudian keduanya disintesakan sehingga didapatkan suatu pema-haman utuh mengenai Tuhan.

Sekilas pendekatan ini mirip dengan Tafsīr Mawd̄̄'̄. Ada kesesuaian di antara keduanya secara metodologi. Perbedaannya, apabila Tafsīr Mawdī' $\bar{\imath}$ hanya membahas satu tema dengan mengevaluasi keseluruhan ayat berkenaan dengan tema tersebut saja, maka Metode Sintetis-Logis mengaitkannya dengan ayat-ayat lain yang memi-liki relevansi dengan tema tersebut. Dengan kata lain, Metode Sintetis-Logis mengakomodir Tafsīr Mawdī' '̄ dengan melanjutkannya pada proses sintesa terhadap tema-tema relevan terkait secara

\footnotetext{
${ }^{6}$ Fazlur Rahman, Islam \& Modernity, 154.
}

logis. Jelas sasaran Fazlur Rahman dengan meto-de ini adalah agar pemahaman terhadap suatu tema tidak bersifat parsial, melainkan menye-luruh dan mendapatkan satu kesatuan yang utuh atas tema tersebut. Dengan demikian-lagi-lagi, diharapkan subjektifitas seorang penafsir dapat dikurangi.

Pendekatan ini sangat kental terasa dalam bukunya, Major Themes of the Quran karena da-lam buku tersebut tema-tema yang dibahas ban-yak berhubungan dengan persoalan metafisis-teologis.

\section{Penerapan Hermeneutika Sintetis- Logis Mengenai Tuhan}

Sebelum membahas lebih dalam bagaimana Fazlur Rahman mengelaborasi pemahaman me-ngenai Tuhan berdasarkan alQur'an, penting untuk dipahami bahwa sekalipun Metode Gerak Ganda tidak bisa dterapkan seutuhnya dalam memahami konsepsi al-Qur'an mengenai Tuhan, tapi bukan berarti karakteristik yang terdapat padanya sama sekali tidak ada dalam Metode Sintetis-Logis. Karakter yang terdapat dalam Pendekatan Sosio-Historis pun tetap muncul dalam Metode Sintetis Logis. Perbedaannya, karakter ini bukanlah suatu bagian integral dari metode itu sendiri. Keberadaannya lebih sebagai suatu tambahan penjelasan yang digunakan oleh Fazlur Rahman dalam memberikan suatu gam-baran relevansi ayat dengan kontekstualisasi kondisi aktual. Sehingga dalam struktur Herme-neutika yang dibangun oleh Fazlur Rahman senantiasa bisa ditemukan bagaimana upayanya dalam menjadikan al-Qur'an sebagai suatu pedoman hidup yang benar-benar hidup untuk manusia di setiap zaman. Ini adalah salah satu modus final yang penting untuk diperhatikan saat

\footnotetext{
${ }^{7}$ Sibawaihi, Hermeneutika Alquran Fazlur Rahman (Yogyakarta: Jalasutra, 2007), 68.
} 
membaca penafsiran yang ia lakukan terhadap ayat-ayat al-Qur'an menggunakan Hermeneutika. Dalam merelevansikan pemahamannya menge-nai Tuhan berdasarkan al-Qur'an pun, hal ini juga dilakukan oleh Fazlur Rahman.

Penafsiran Fazlur Rahman mengenai Tuhan secara mendalam bisa disimak dalam karyanya, Major Themes of the Quran. Baginya, Tuhan adalah satu yang sentral. Ini tampak dalam susu-nan pembahasannya dalam buku ini, di mana ia meletakkannya di awal pembahasan dari berbagai pembahasan metafisisnya. Sejak awal ia mene-gaskan bahwa sebagai petunjuk bagi manusia, titik tekan penjelasan al-Qur'an mengenai Tuhan bukanlah suatu penjelasan yang diarahkan untuk tujuan spekulasi-teologis sebagaimana yang acap-kali ditemukan dalam kajian-kajian teologis-filo-sofis. Sekalipun penjelasan sejenis ada dalam al-Qur'an, tapi selalu diarahkan kepada suatu yang bersifat fungsional: agar manusia mengenal-Nya, mengimani-Nya, kemudian berakhlak kepadaNya sebagaimana harusnya akhlak makhluk kepada Penciptanya.

"Tetap saja, al-Qur'an bukanlah risalah mengenai Tuhan dan sifat-sifat-Nya: wujudNya, karena al-Qur'an, tegasnya adalah fungsional-Ia adalah Sang Pencipta dan Sang Pemelihara alam semesta dan manusia, dan khususnya Sang Pem-beri Petunjuk bagi manusia dan Ia yang mengha-kimi manusia, secara individu dan kolektif, dan kembali pada-Nya keadilan yang oenuh rahmat"s

Dalam kaitannya dengan ini, maka ia beru-paya merelevansikannya dengan kondisi aktual. Di antaranya ia menjelaskan bahwa terdapat kerancuan yang ditimbulkan oleh para orientalis yang dijustifikasi dengan pembacaan

8 Fazlur Rahman, Major Themes of the Qur'an (Minneapolis-Chicago: Bibliotheca Islamica, 1994), 1. mereka kepada sejumlah literatur yang ditulis oleh se-jumlah intelektual muslim masa lalu. Sayangnya, sejumlah penulis modernbahkan dari kalangan muslimpun-acapkali terjebak dalam pola pikir yang dibangun oleh para orientalis ini. Saat mereka menelaah mengenai beberapa nama dan sifat Tuhan dalam al-Qur'an, seolah mereka men-dapati sosok Tuhan yang yang semena-mena, kejam, mengazab siapapun yang tidak mau tunduk kepada-Nya, dan semacamnya. Konsepsikonsepsi seperti ini tentu terlalu simplistis, tidak bisa diterima, dan jelas sangat gegabah, karena bahkan ayat pertama yang disuguhkan dalam al-Qur'an bermakna, “Dengan nama Allah Yang Maha Pengasih (lagi) Maha Penyayang" (1:1). Sementara pada ayat terakhir, al-Qur'an meng-ajarkan kepada pembacanya untuk berlindung kepada Tuhan dari kejahatan yang bersumber, “..dari jin dan manusia” (114:6). Keduanya menunjukkan kasih sayang Tuhan kepada makhluk-Nya. Selebihnya, ribuan ayat yang terbentang di antara kedua ayat tersebut menyam-paikan berbagai hal berkenaan dengan Tuhan dalam banyak konteks.

Sekalipun begitu, Fazlur Rahman enggan untuk terjebak pada pemaparan teologis mengenai nama dan sifat Tuhan. Menurutnya bukan ini sasaran sesungguhnya dari al-Qur'an, melainkan bagaimana berbagai fakta yang terbentang di alam semesta ini seharusnya sudah cukup mem-bangkitkan keinginan makhluk untuk mengenal-Nya tanpa perlu merumitkan realitas, membebani pikiran dan jiwa. Membawa pere-nungan tersebut kepada penjelasan al-Qur'an bahwa keyakinan kepada yang lebih superior dari alam semesta ini sebagai suatu yang gaib (2:3, 5:94, 21:49). Walau ada pribadi-pribadi seperti Nabi 
Muhammad yang mampu memahaminya hingga batasan ter-tentu, tetaplah ia suatu hal yang gaib dan pema-haman itupun tidak lepas dari al-Qur'an. Sudah pun demikian, tetap saja tidak ada yang bisa memahami hakikat Tuhan selain diri-Nya sendiri (7:188, 11:31, 12:81). Sampai di sini bisa dipa-hami bahkan alQur'an pun tidak bisa mengantar-kan pembacanya pada pengetahuan akan hakikat zat-Nya. Bagi Fazlur Rahman, sesungguhnya yang diinginkan dengan pewahyuan al-Qur'an adalah agar siapapun bisa merenungkan berbagai penjelasan dalam al-Qur'an mengenai keberadaan Tuhan seiring interaksi mereka dengan alam semesta. Sehingga ia tidak hanya akan berpikir bahwa Tuhan adalah sosok gaib transenden yang tidak mungkin terjangkau oleh nalar akal atau kedalaman intuitif sekalipun, melainkan meng-ubah konsepsi kegaiban akan keberadaan Tuhan seperti ini menjadi suatu konsepsi bahwa Ia adalah Pemilik Kebenaran (the Master-Truth). Perubahan konsepsi inilah sesungguhnya yang menjadi sasaran al-Qur'an bagi para pembacanya.

Itulah mengapa di antara nama yang diberikan kepada al-Qur'an adalah al-Dhikr (Peringatan). Maka dalam upaya mengingatkan manusia akan keberadaan Tuhan, Fazlur Rahman menyimpulkan penjelasan al-Qur'an mengenai Tuhan: ${ }^{9}$

- Bahwa apapun selain Tuhan adalah bergantung kepada Tuhan, termasuk keseluruhan alam (yang memiliki aspek metafisis dan moral).

- Bahwa Tuhan, dengan segala kedigdayaan dan keagungan-Nya, secara esensial adalah Tuhan Yang Maha Pengasih.

- Bahwa kedua aspek ini secara niscaya menghadirkan sebuah relasi yang patut antara Tuhan dan manusia-sebuah relasi yang diabdi dan pengabdi-dan konsekuensinya juga sebuah relasi yang patut antarmanusia. Secara alami, niscaya relasi-relasi normatif ini menghadirkan hukum pengadilan atas manusia sebagai individu dan dalam eksistensi kolektif atau sosialnya.

Lebih lanjut, Fazlur Rahman menjelaskan bahwa ketika tiga hal ini dipahami maka sentralitas absolut Tuhan dalam kaitannya dengan wujud akan dipahami juga. Hal ini karena sasaran utama al-Qur'an adalah manusia dan bukan pem-bahasan mengenai Tuhan itu sendiri.

\section{a. Segala Sesuatu Bergantung kepada Tuhan}

Fazlur Rahman mengawali penjelasan tentang ketergantungan segala sesuatu kepada Tuhan dengan menjelaskan mengenai ketiadaan. Secara teoritis, menurutnya ketiadaan adalah suatu hal yang mungkin untuk dibayangkan, sebagaimana misalnya kita bisa membayangkan ketiadaan alam semesta. Tapi sesungguhnya ketiadaan itu sendiri adalah mustahil. Ketiadaan sendiri hanya bisa dipahami melalui keadaan. Itulah mengapa menurutnya Hegel mengatakan bahwa 'tiada' adalah adalah satu kata yang hampa dan tidak memiliki makna. Karenanya, alam semesta sendiri adalah suatu hal yang niscaya bagi keadaan. Dengan demikian ada suatu ketergantungan mutlak bagi keadaan sesuatu, seperti alam semesta. Dia mengumpamakannya seperti mainan yang diberikan kepada seorang bocah, sehingga mainan itu sendiri bersifat niscaya bagi bocah tersebut.

Adapun ketergantungan itu sendiri tidak bisa dibayangkan tanpa adanya suatu yang

\footnotetext{
${ }^{9}$ Fazlur Rahman, Major Themes of the Qur'an, 2.
} 
dengannya ia bergantung. Tapi keasyikan manusia dalam memperhatikan segala sesatu yang tergantung tersebut menjadikannya lalai dalam memperha-tikan yang menjadi gantungan bagi ketergantung-an tersebut. Laiknya seorang anak kecil yang ber-main ayunan, ia hanya akan fokus kepada tempat ia bisa duduk dan bermain ayunan tanpa perlu memperhatikan tiang yang menjadi tempat ber-gantung tempat ayunan tersebut. Padahal, tiang itu sendiri adalah suatu realitas yang sama dan pasti sebagaimana ayunan yang ia mainkan. Demikianlah manusia dalam menyikapi realitas. Sudah seharusnyalah ketika ia melihat realitas alam semesta ini, ia merenungkan asal-muasal dan tujuan akhir dari keberadaan alam semesta ini.

Fazlur Rahman tidak menyatakan argumen-tasinya ini sebagai bukti keberadaan Tuhan, karena baginya keberadaan Tuhan itu sendiri hanya bisa dipahami apabila manusia datang sendiri 'mencari'-Nya, "Dan hak bagi Allah (menerangkan) jalan yang lurus, dan di antara jalan-jalan ada yang bengkok" (16:9). Tapi 'mencari' di sini bukanlah sebuah ungkapan biasa, karena ia memerlukan perubahan cara pandang kita terhadap struktur realitas. Tuhan bukanlah bagian dari realitas sesuatu apapun, Ia bukan Satu entitas sebagaimana keberadaan entitas-entitas yang lain. Hal ini dikarenakan Ia tidak bergantung kepada sesuatu apapun, bahkan segala sesuatulah yang bergantung kepada-Nya.

Segala sesuatu di alam ini adalah terhingga dan seluruhnya bergantung kepada Yang tak ter-hingga, yakni Tuhan. Di antara tanda ketakter-hinggaan-Nya adalah, "Katakanlah: Kalau sekiranya lautan menjadi tinta untuk (menulis) kalimat-kalimat Tuhanku, sungguh habislah lautan itu sebelum habis (ditulis) kalimat-kalimat Tuhanku, meskipun Kami datangkan tambahan sebanyak itu (pula)" (18:109). Seiring dengan ini, maka tidak ada yang setara dengan-Nya. Apabila terdapat lebih dari satu Tuhan, maka salah satu di antaranya akan mengungguli yang lain. Tentu kondisi tersebut absurd bila dikaitkan dengan sifat ketakterhinggaan, "Katakanlah: Jikalah ada tuhan-tuhan di samping-Nya, sebagaimana yang mereka katakan, niscaya tuhan-tuhan itu mencari jalan kepada Tuhan yang mempunyai 'arsy", (17:42).

Sehingga jelaslah bahwa alam inipun adalah bagian dari ciptaan-Nya dan bekerja sesuai dengan hukum yang telah ditentukan oleh-Nya, yakni kausalitas alami. Tetapi keberadaan kau-salitas alami inipun tidak berarti menjadikan-Nya pasif atau tidur. Tidak pula berarti menjadikan alam ini terlepas dari kuasa-Nya. Tanpa-Nya, alam dan manusia tidak akan bekerja sebagai-mana mestinya. Sebagai realitas, manusia dan segala sesuatu lainnya memiliki hubungan yang langsung dengan Tuhan sebagaimana mereka memiliki hubungan yang langsung dengan sesamanya. Dialah yang menyebabkan segala sesuatu di alam semesta ini saling terintegrasi. Tetapi bukan berarti bahwa Tuhan adalah bagian dari keterintegrasian tersebut. Sehingga, "Dan janganlah kamu seperti orang-orang yang lupa kepada Allah, lalu Allah menjadikan mereka lupa kepada diri mereka sendiri" (59:19).

Itulah mengapa al-Qur'an acapkali menekan-kan kekuasaan dan keagungan Allah:

"Dialah Allah Yang tiada Tuhan (yang berhak disembah) selain Dia, Yang Mengetahui yang ghaib dan yang nyata, Dialah Yang Maha Pemurah lagi Maha Penyayang. Dialah Allah Yang tiada Tuhan (yang berhak disembah) selain Dia, Raja, Yang Maha Suci, Yang Maha Sejahtera, Yang Mengaruniakan keamanan, Yang Maha Memelihara, Yang 
Maha Perkasa, Yang Maha Kuasa, Yang Memiliki Segala Keagungan, Maha Suci Allah dari apa yang mereka perse-kutukan. Dialah Allah Yang Menciptakan, Yang Mengadakan, Yang Membentuk Rupa, Yang Mempunyai Nama-nama Yang Paling Baik. Bertasbih kepada-Nya apa yang ada di langit dan di bumi. Dan Dialah Yang Maha Perkasa lag Maha Bijaksana." (QS. al-Hashr: 22-24).

\section{b. Tuhan Adalah Yang Maha Pengasih}

Fazlur Rahman mengiringkan pembahasan ke-MahaPengasihan Tuhan dengan mengutip QS. al-Naml: 60-64 berikut:

"Atau siapakah yang telah menciptakan langit dan bumi dan yang menurunkan air untuk-mu dari langit, lalu Kami tumbuhkan dengan air itu kebun-kebun yang berpemandang-an indah, yang kamu sekalikali tidak mampu menumbuh-kan pohonpohonnya? Apakah di samping Allah ada tuhan (yang lain)? Bahkan (sebenarnya) mereka adalah orang-orang yang menyimpang (dari kebenaran).

Atau siapakah yang telah menjadikan bumi sebagai tempat berdiam, dan yang menjadikan sungai-sungai di celah-celahnya, dan yang men-jadikan gunung-gunung untuk (mengokohkan) nya dan menjadikan suatu pemisah antara dua laut? Apakah di samping Allah ada tuhan yang lain? Bahkan (sebenarnya) kebanyakan dari mereka tidak mengetahui.

Atau siapakah yang memperkenankan (doa) orang yang dalam kesulitan apabila ia berdoa kepada-Nya, dan yang menghilangkan kesusahan dan yang menjadikan kamu (manusia) sebagai khalifah di bumi? Apakah di samping Allah ada tuhan (yang lain)? Amat sedikitlah kamu mengingati(-Nya).

Atau siapakah yang memimpin kamu dalam kegelapan di daratan dan lautan dan siapa (pula)kah yang mendatangkan angin sebagai kabar gembira sebelum (kedatangan) rahmat-Nya? Apakah di samping Allah ada tuhan (yang lain)? Maha Tinggi Allah terhadap apa yang mereka persekutukan (dengan-Nya).

Atau siapakah yang menciptakan (manusia dari permulaannya), kemudian mengulanginya (lagi), dan siapa (pula) yang memberikan rezeki kapadamu dari langit dan bumi? Apakah di samping Allah ada tuhan (yang lain)? Katakan-lah: 'Unjukkanlah bukti kebenaranmu, jika kamu memang orang-orang yang benar."'

Di samping menunjukkan kekuasaan-Nya, ayat-ayat di atas juga menunjukkan ke-Maha Pengasihan Allah yang tak terhingga melalui berbagai ciptaan-Nya. Keluasan karunia-Nya ini tidak hanya bisa dimaknai secara transenden, melainkan juga mengiringi ciptaan-Nya dalam suatu bentuk kebersamaan yang dikatakan, “..dan Kami lebih dekat kepadanya daripada urat lehernya" (50:16). Maka bukanlah suatu yang janggal bila Ia menerima taubat setiap hamba yang kembali menemui-Nya seberapapun dahsyat kesalahan yang telah dilakukan oleh sang hamba karena Ia adalah Yang Maha Penerima Taubat (alTawwāb) $(2: 37,54,160,182)$ dan Yang Maha Pengampun (al-Ghafūr) (2:173, 182, 192). Allah mengubah semua perilaku buruk mereka yang telah bertaubat dan diampuni tersebut menjadi kebajikan (25:70).

Al-Qur'an senantiasa mengulang kemahakuasaan dan kemahabesaran Allah untuk mene-gaskan bahaya kebodohan manusia yang men-jadikan suatu yang terhingga setara dengan Yang Tak Terhingga. Mereka memohon dan meng-gantungkan diri mereka kepada sesuatu yang terhingga tersebut, padahal mereka memiliki hubungan langsung dengan-Nya Yang Tak Ter-hingga. Itulah mengapa Allah menyatakan petunjuk-Nya 
sebagai cahaya (24:35) yang di-perhadapkan dengan kegelapan yang berlapis-lapis (24:40) sebagai kebodohan karena menjauhi bahkan menentang petunjuk-Nya.

Fazlur Rahman menyangkal keyakinan sebagian orang yang mengatakan bahwa alam semesta ini muncul dikarenakan suatu kondisi kebetulan antarentitas yang saling mempengaruhi. Dia juga menolak keyakinan para sufi yang meyakini hadits analogis Allah sebagai harta terpendam yang berhasrat untuk ditemukan. Baginya semua pendapat tersebut menyiratkan seolah penciptaan alam semesta termasuk manu-sia di dalamnya hanyalah permainan belaka. Pa-dahal al-Qur'an telah dengan gamblang menya-takan bahwa, "Dan tidaklah Kami ciptakan lang-it dan bumi dan segala yang ada di antara ke-duanya dengan bermain-main" (21:16). Dia me-nandaskan bahwa ada suatu tujuan primordial sejati dari segala penciptaan yang dipenuhi deng-an keMahaPengasihan-Nya ini,yakni pengabdian.

\section{c. Pengabdian}

Dalam al-Qur'an, secara gamblang dinyata-kan bahwa tujuan hidup manusia adalah untuk beribadah kepada Allah, sebagai khalifah di dunia. Fazlur Rahman menjelaskan:

"Sementara tujuan manusia adalah untuk "mengabdi" kepada Tuhan, yaitu, mengembang-kan potensialitaspotensialitasnya yang lebih tinggi sesuai dengan "perintah" (amr) Tuhan, me-lalui pilihan, dan mendayagunakan alam (yang secara otomatis adalah muslim "berserah kepada Tuhan"), ia mesti dilengkapi dengan maksud-maksud keberlangsungan yang memadai dan "menemukan jalan yang benar". Karenanya Tuhan, Yang dengan curahan
rahmat-Nya telah mengaruniakan manusia dengan kesadaran yang diperlukan dan kemauan untuk menciptakan pengetahuan dan menggunakannya untuk merea-lisasikan tujuan-tujuan kelaikan dan keadilan-Nya. Pada titik inilah ujian krusial manusia hadir: apakah ia menggunakan pengetahuan dan daya-nya untuk kebaikan atau untuk kejahatan, karena "berhasil atau gagal", atau untuk "memakmurkan bumi atau merusaknya" (sebagaimana secara konstan disampaikan alQur'an)?"10

Dengan ke-MahaPengasihan-Nya, manusia dihadirkan ke dunia disertai dengan berbagai potensi yang dapat digunakan untuk memakmur-kannya. Sejak awal manusia telah dianugerahi hidayah yang dengannya bisa membedakan antara yang baik dan yang jahat (91:8). Pun sejak awal manusia telah menyatakan ikrar ketauhidan kepada dan di hadapan Allah (7:172). Dengan ini saja sebenarnya cukuplah bagi manusia untuk menyadari tujuan hidupnya. Tapi Allah Yang Maha Pengasih terus menurunkan rahmatNya, yakni dengan mengutus para nabi dan rasul berikut wahyu yang disampaikan melalui mereka untuk manusia.

Keseluruhan rangkaian yang telah dijelaskan ini: penciptaan, pemeliharaan, petunjuk, pertim-bangan, seluruhnya merupakan manifestasi dari ke-Maha Pengasihan Allah. Semua ini sedemi-kian lugas tertera dalam al-Qur'an dan sedemi-kian logis menurut seluruh potensi manusia. Sehingga wajarlah al-Qur'an mencantumkan kehe-ranan apabila masih saja ada yang tidak mampu menangkap semua pesan ini bahkan menentang-nya, baik dalam bentuk ateisme, materialisme, dan berbagai bentuk mempersekutukan Allah lainnya.

\footnotetext{
${ }^{10}$ Fazlur Rahman, Major Themes of the Qur'an, 6.
} 
Menurut Fazlur Rahman, demikianlah alQur'an bekerja. Ia tidak berusaha membuktikan keberadaan Allah, melainkan berusaha menjelas-kan cara untuk 'menemui' Allah melalui berbagai potensi yang ada dalam diri manusia dan alam semesta. Seorang yang telah 'menemui' Allah, maka ia akan menjadi pribadi yang kokoh. Dia meyakini bahwa Allah akan melindungi dan me-nolongnya. Fazlur Rahman menjelaskan bahwa dalam QS. al-Ikhlāṣ, Allah disebut dengan al-Șamad yang memiliki makna karang kokoh yang tidak dapat digoyahkan atau dihancurkan sehing-ga laik untuk dijadikan tempat berlindung. Sebaliknya, "Perumpamaan orang-orang yang meng-ambil pelindung-pelindung selain Allah adalah seperti laba-laba yang membuat rumah. Dan sesungguhnya rumah yang paling lemah ialah rumah laba-laba kalau mereka mengetahui." (29:41).

\section{d. Qādir - Maqdūr}

Fazlur Rahman menghadirkan konsep $q \bar{a}$ dir-maqdūr. Konsep ini tidak sama dengan per-debatan mengenai predeterminisme dalam Ilmu Kalam. Berawal dari konsep qadar yang pada zaman sebelum Islam dimaknai sebagi takdir atau suatu kekuatan yang tidak bisa diketahui dan dikendalikan oleh manusia tapi ketetapannya berlaku bagi manusia, oleh alQur'an pemaknaan kata ini berubah menjadi suatu konsep kekuasaan Tuhan yang bermaksud atas segala ciptaan-Nya. ${ }^{11}$ Allah Yang Maha Pengasih dan Tak Terhingga memberikan ukuran-ukuran tertentu kepada se-tiap ciptaan-Nya (77:23). Ukuran-ukuran ini ber-asal dari ke-TakTerhinggaan-Nya yang tentu saat melekat kepada ciptaan-Nya menjadi suatu ukuran yang terhingga. Dengan segala ukuran yang diberikan inilah keteraturan di alam semesta tercipta. Di samping itu, ungkapan ini juga digunakan dalam al-Qur'an dalam bentuk perin-tah (amr) yang erat hubungannya dengan pembe-rian ukuran (3:83, 7:206, 13:15, 16:49, 17:44, 21:19, 22:18, 55:6, 57:1, 59:1, 61:1).

Dengan demikian, tentu saja konsep ini melahirkan Yang Memerintah (Āmir) yang juga Yang Memberikan Ukuran ( $Q \bar{a} d i r)$, yakni Allah. Maka segala sesuatu yang berada di bawah perintah(ma'mur)-Nya adalah berada di bawah ukuran(maqdūr)-Nya. Allah tidak terjangkau oleh apapun juga sehingga ia tidak terhingga. Ketak-terhinggaan-Nya termanifestasi dalam berbagai nama dan sifatNya. Alam semesta-termasuk manusia di dalamnya - adalah manifestasi dari ketakterhinggaan kuasa dan kasih-Nya. Akan tetapi manifestasi tentu berbeda dari Yang dimaniifestasikan. Alam semesta tentu terhingga dan memiliki batasan sehingga ia terukur, itulah sebabnya ia dikatakan yang terukur (maqdūr). Allah Yang bersifat tak terhingga telah mencip-takan segala sesuatu menurut ukurannya (54:49).

Penting untuk diperikan lebih lanjut antara alam dan manusia. Apabila alam sama sekali tunduk-patuh kepada Allah-maka tak ayal lagi bila dikatakan ia adalah 'muslim' (yang berserah diri) — secara total, maka ketundukan manusia kepada Allah menjadi suatu perintah moral. Sekalipun manusia diperintahkan untuk meng-abdi kepada Allah — sebagaimana tujuan hidup-nya, akan tetapi ia bisa saja membantah perintah ini. Sehingga disposisi pengabdian manusia tidak bisa disamakan dengan alam semesta. Kepada manusia dibebankan tanggung jawab yang kelak mesti dipertanggungjawabkan kepada Yang Maha Memberi Ukuran. Di dunia, tanggung jawab tersebut mesti ditunaikan dengan taqwa. Al-

\footnotetext{
${ }^{11}$ Fazlur Rahman, Major Themes of the Qur'an, 8.
} 
Qur'an banyak memberikan penegasan akan hal ini $(6: 14-15 ; 10: 35 ; 19: 90-92 ; 22: 73-74$; $25: 43 ; 42: 4-5 ; 109: 1-6)$.

Berkenaan dengan disposisi pengabdian manusia, maka ungkapan bahwa "Allah tidak memberikan petunjuk kepada orang-orang yang aniaya" dan sejenisnya atau ungkapan "Allah memberikan petunjuk kepada orangorang yang beriman” dan sejenisnya menjadi jelas. Bagi Fazlur Rahman itu semua kembali kepada manusia itu sendiri $(2: 26,258,264$; 3:86; 5:16, 51, 67, 108; 6:88, 144; 9:19, 21, 37, 80,$109 ; 12: 52 ; 13: 27 ; 16: 37,107 ; 28: 50 ; 39: 3$; 40:28; 42:13; 46:10; 61:5, 7; 62:5; 63:6). Sikap apa yang akan manusia pilih, yang pasti semua pilihan itu akan dipertanggungjawabkannya kelak.

\section{Tuhan dalam al-Mīzān fi Tafsīr al-Qurān}

1. 'Allāmah Al-Ṭabātạabā'ì dan al-Mīzān fi Tafsīr al-Qurān

Beliau adalah Muḥammad Ḥusayn ibn Muḥammad ibn Muhammad Husayn. Lahir di Tabriz pada tanggal 17 Maret 1904 (29 Dzulhijjah 1321). Nasabnya bersambung hingga Imam Hasan dan Imam Husayn sehingga laqab-nya bisa dituliskan dengan alHasan̄̄ dan al-Husaynī sekaligus. Tapi laqab yang terkenal adalah al-Ṭabāțabā'̄̄ yang berasal dari salah satu leluhurnya, Ibrāhīm ibn Ismā’il al-Dībāj al-Hasanī yang lebih dikenal dengan Thabāthabā. ${ }^{12}$ Keluarga al-Ṭabāṭabā'̄ adalah satu keluarga besar yang terkenal selama tiga abad hingga kelahiran Muhammad Husayn karena silih berganti mela-hirkan generasi ulama yang masyhur di Azerbaijan (Iran).

12 Muhammad Taq̄i Anshāriyān al-Khwānsārī, Ma 'rūf fì as-Samā' wa Kafa bi Dzalika Majadan: Dzikriyyāt wa Watsāiq Tansyir li Awwal Marrah Hawla Hayāh wa Sīrah al-`Allāmah ar-Rāhil as-Sayyid
Pendidikannya di Najaf sangat berpengaruh dalam membentuk intelektualitas Muhammad Ḥusayn al-Ṭabātabā'̀̄. Penting disebutkan bahwa ada dua guru yang sangat berpengaruh padanya, yakni Syaikh Muhammad Husayn Nā'̄̄n̄̄ al-Gharawī dan Syaikh Muḥammad Husayn al-Gharawī alIshfahānī. Dari sosok yang pertama ia mempelajari Fiqh dan Ushul. Adapun sosok kedua adalah seorang filsuf yang sangat cemer-lang, ahli sastra baik dalam Bahasa Arab sekaligus Persia, dan seorang yang dikenal sangat jenius. Selain Filsafat, darinya ia juga mem-pelajari Ushul Fiqh dan Fiqh. Sehingga tak dapat disangkal dari kedua guru yang sangat berpeng-aruh padanya ini, Syaikh Muḥammad Ḥusayn al-Gharawī al-Ishfahān̄̄ lebih ber-pengaruh dalam membentuk intelektual al-Ṭabāțabā'̄i. Guru ketiga yang sangat berpengaruh padanya adalah Sayyid Abū al-Qāsim Ja far Khwānsārī yang dikenal sebagai seorang yang sangat ahli dalam Matema-tika sehingga al-Ṭabāṭabā'̄ sangat bangga telah belajar Matematika darinya. Kemudian, Sayyid Husayn al-Ḥusayn̄̄ Bādkūbah`̄ yang darinya al-Ṭabātabā'̄̄̄ mempelajari al-Manzhūmah alSabzawāriyyah, Asfār karya Mullā Shadrā, alShifā' karya Ibn Sīnā, dan al-Utsūlūjiyyā karya Ibn Turkah al-Ishfahānī. Selanjutnya, Sayyid 'Alī al-Qādh̄̄ yang darinya ia mempelajari Irfan al-'Amalī. Sebagai seorang yang menempuh pendi-dikan di Najaf yang merupakan kota penting dalam pendidikan di Dunia Syiah kala itu, tentu seluruh gurunya ini sangat mem-pengaruhi al-Ṭabātabā'̄ tidak hanya dalam aspek intelek-tualitas tapi juga spiritualitas. $^{13}$

Muhammad Husayn ath-Thabāthabāī (Qum: Muassasah Anshāriyān li ath-Thibā'ah wa an-Nasyr, 2015), 7-8.

${ }^{13}$ Fazlur Rahman, Major Themes of the Qur'an, 16- 
Sekembalinya ia ke Tabriz setelah menem-puh pendidikan di Najaf, 'Allāmah alṬabāțabā'̄ menulis tafsir al-Qur'an dari awal hingga QS. al-A 'rāf. Tafsir yang ditulisnya ini bersamaan dengan beberapa catatan lain, awalnya digunakan untuk mengajar Tafsir. Tapi kemudian ia memu-tuskan untuk meneruskan tafsirnya tersebut dengan tujuan untuk memberikan pengajaran yang lebih jauh demi memenuhi tuntutan dunia kontemporer. Maka hadirlah al-Mīzān fì Tafsìr al-Qur'ān dalam 20 jilid. Penulisan tafsir ini dimulai sekitar tahun 1955 dan diselesaikan pada tanggal 30 Oktober 1972 (23 Ramadhan 1392). Sepanjang penulisan tafsir ini, ia tetap menggu-nakannya sebagai bahan ajar Tafsir hingga ia menetap di Qum. ${ }^{14}$

Sebelumnya, perlu diperhatikan bahwasanya 'Allāmah al-Ṭabāțabā'̄ membedakan antara al-tafsīr dan al-tațbìq. Yang pertama adalah men-jelaskan maknamakna dari ayat-ayat al-Qur'an, menyingkapkan maksud-maksudnya, dan implikasi-implikasinya. Adapun yang kedua adalah membahas seputar apa yang terkandung dalam ayat-ayat berkenaan makna yang sesuai dengan pandangan yang telah dibangun sebelum-nya baik bersifat teologis, filosofis, sufistis, ilmiah, deskriptif, dan lain-lain. ${ }^{15}$ Pemeriannya atas kedua hal ini tak lepas dari pandangannya bahwa sejak abad kedua para ulama terbagi dalam beberapa rumpun keilmuan yang mereka miliki, yakni kalam, filsuf, sufi, dan ahli hadits. Masing-masing memahami al-Qur'an secara parsial sesuai dengan bidang ilmu yang mereka kuasai. Ditambah lagi, di era kontemporer ada

14 Sayyid Muhammad Husayn Husayni Tihrani, Shining Sun: In Memory of 'Allamah Tabataba'i (London: ICAS Press, 2011), 46.

15 'Al̄̄ Jābir Āli Shafā, Nazhariyah al-Ma'rifah wa al-Idrākāt al-I`ibāriyah inda al-'Allāmah athThabāthabāī (Beirut: Dār al-Hādī, 2001), 41. sebagian orang yang mencoba mencocokcocokan ayat-ayat al-Qur'an dengan berbagai penemuan ilmu pengetahuan modern yang juga sesungguhnya bersifat parsial.

"Dan anda dengan memperhatikan seluruh metode pengutipan dalam tafsir akan mendapati: sesungguhnya semuanya berserikat dalam keku-rangan dan kelemahan, karena menghadirkan apa yang dihasilkan dari pembahasan ilmiah atau filosofis di luar tujuan ayat-ayat. Maka berubah-lah tafsir (al-tafsìr) dengan penyesuaian (al-tațbiq $)$ dan menyebut penyesuaian dengan tafsir. Maka jadilah karenanya hakikat-hakikat dari al-Qur'an dengan majaz-majaz, dan aspek tanzīl dari sejumlah ayat tereduksi demi $t a$ 'wīl."'16

Adapun penamaan 'al-Mīzān' dikarenakan tafsir ini dilengkapi dengan banyak membentang-kan pandangan dan pendapat para mufassir dan selainnya, menguji, membandingkan dan menim-bang pandangan-pandangan dalam satu tema kemudian menguatkan atau menolak di antaranya.

\section{Cara Mengenal Tuhan Menurut al- Qur'an dalam Tafsir al-Mīzān}

Sejak dulu telah banyak para intelektual muslim menghadirkan berbagai bukti yang memunjukkan keberadaan Tuhan dengan berbagai macam metode. Di kalangan filsuf ada sejumlah metode yang digunakan dalam hal ini. Di antara yang terkenal adalah dengan pemilahan wujud antara wäjib (necessary) dan mumkin (contingent), ringkasnya argumentasi ini me-nyatakan bahwa berbagai macam wujud yang terdapat di dunia ini sesungguhnya

16 Al- Allāmah al-Sayyid Muhammad Husayn alṬabāțabāī, al-Mīzān fì Tafsīr al-Qurān, jil. 1 (Beirut: Mansyūrāt Muassasah al-A 'lāmī li al-Mathbū āt, 1997), 11. 
adalah mumkin al-wujūd yang tidak mungkin terwujud kecuali dengan keberadaan Wājib alWujūd. Selain itu terdapat Burhān al-Limmī dan Burhan al-Innī. Yang pertama membuktikan keberadaan Tuhan yang didasarkan pada sebab yang menis-cayakan akibat, sedangkan yang kedua adalah sebaliknya. Ada pula Burhān al-Harakah yang mendasarkan pembuktiannya pada keniscayaan akan Penggerak Yang Tak Bergerak agar tidak terjadi tautologi dalam kosmos. Sedangkan ahli kalam pada umumnya menggunakan Burhān al-Hudūth untuk menunjukkan bahwasanya apapun yang tidak lepas dari kebaruan adalah baharu dan pasti berawal.

Sebagai seorang mufassir sekaligus filsuf yang dibesarkan di Persia, tentu pengaruh Mulla Shadra tak lepas dari sistem filsafat 'Allāmah al-Ṭabātabā'̄̄. Demikian pula halnya pemahaman-nya mengenai Tuhan. Pada dasarnya 'Allāmah al-Ṭabāṭabā'̄ tidak menghadirkan argumentasi baru mengenai bukti keberadaan Tuhan. Dia sepenuh-nya mengadopsi Burhān al-Shiddīqīn yang disampaikan oleh Mulla Shadra, hanya saja ia memberikan elaborasi yang lebih dalam pembuktiannya.

Mulla Shadra menjelaskan bahwa ada tiga prinsip dasar wujud, yakni ashalah al-wujūd, wahdah al-wujūd, dan tasykīk al-wujūd. Ashalah al-wujūd menyatakan bahwasanya wujud adalah realitas dasar yang paling nyata dan jelas (badihī). Wahdah al-wujud sepenuhnya diadopsi Mulla Shadra dari pandangan Syaikh al-Akbār Ibn `Arabī, hanya saja ia memberikan penjelasan melalui tasykīk

17 Achmad Muchaddam Fahham, Tuhan dalam Filsafat 'Allāmah Thabāthabāì: Relevansi Pandangan Moral dengan Eksistensi Tuhan dalam Realisme Instingtif (Yogyakarta: RausyanFikr Institute, 2012), 79-80. al-wujūd bahwa secara hirarkis wujud memiliki perbedaan dalam intensitasnya.

Bagi `Allāmah al-Ṭabātabā'̀̄, Burhān ashShiddīin adalah argumentasi pembuktian terbaik karena ia mendasarkannya kepada wujud Tuhan bukan kepada yang lain dalam pembuktiannya. Berangkat dari hal ini, 'Allāmah al-Ṭabāṭabā'̄ membangun elaborasinya dalam membuktikan keberadaan Tuhan, yakni dengan realisme instingtif yang dibangun berdasarkan fitrah manusia. Premis yang digunakan olehnya dalam membangun metodenya ini: ${ }^{17}$

- Fitrah manusia menyadarkan bahwa ia adalah wujud yang nyata dan pada saatnya akan hancur, sehingga meniscayakan untuk bergantung pada suatu yang tetap dan tidak bisa hancur. Jika hubungan ketergantungan ini tidak ada, maka keberadaan manusia adalah mustahil.

- Kesadaran pertama di atas, menghadirkan kesadaran baru terhadap berbagai fenomena wujud lainnya. Bahwa antara dirinya dan alam saling terkait dalam wujud. Dengan demikian, niscaya ada satu sumber wujud yang menjadi sandaran dari berbagai fenomena wujud ini. Sumber dimaksud adalah Tuhan.

‘Allāmah al-Ṭabāṭabā'̄ menjelaskan bahwasanya, realisme instingtif ini sebenarnya terdapat dalam banyak ayat al-Qur'an (14:10; $20: 50 ; 31: 25 ; 43: 87 ; 45: 3-6)$, sehingga ia menyebutnya juga dengan 'Cara mengenal Tuhan Menurut al-Qur'an'.18
18 Achmad Muchaddam Fahham, Tuhan dalam Filsafat 'Allāmah Thabāthabā̄i, 80. 


\section{a. Ketakterhinggan Allah Tak Sebanding Keterhinggaan Ciptaan-Nya}

'Allāmah al-Ṭabāțabā'̄ menjelaskan bahwa kata "kalimat-kalimat" (al-kalimāt) dalam QS. al-Kahf: 109 tidak tepat ditafsirkan sebagai segala sesuatu yang Allah ketahui, tetapkan, janjikan dan ancamkan, meskipun dalam konstruksi kalimatnya, “..sungguh habislah lautan itu sebelum habis (ditulis) kalimat-kalimat Tuhanku, meskipun Kami datangkan tambahan sebanyak itu (pula)" (18:109). Meskipun benar bahwasa-nya ketakterhinggaan pengetahuan Allah tidak bisa digambarkan dengan keterhinggaan lautan, akan tetapi sebenarnya bukan itu yang ingin disampaikan oleh ayat ini. Dengan kata lain, terlalu jauh menyandingkan "al-kalimāti Rabbī" dengan "al-bahr". Pengulangan kata 'lautan' (al-bahrr) dan 'Tuhanku' (Rabbī) justru meng-indikasikan hanya kepada fakta yang dirujuk, bukan yang lain. ${ }^{19}$ Ayat ini bukan meng-gambarkan ketakterhinggan pada Allah, melain-kan menggambarkan betapa kecil dan remeh pengetahuan manusia sehingga untuk dibanding-kan dengan pengetahuan Allah pun tak layak.

\section{b. Ke-Maha Pengasihan Allah Adalah Keniscayaan Ketuhanan-Nya}

Berkenaan dengan sifat keMahaPengasihan Allah, penting untuk memperhatikan tafsir yang disampaikan oleh 'Allāmah al-Ṭabāṭabā'̄ ber-kenaan dengan, "Kemudian Adam menerima beberapa kalimat dari Tuhannya, maka Allah menerima taubatnya. Sesungguhnya Allah Penerima taubat lagi Maha Penyayang." (2:37). KeMahaPengasihan Allah jelas tampak dari

${ }^{19}$ al-Ṭabāṭabāī, al-Mīzān fì Tafsīr al-Qurān, jil. 13, 399-400

${ }^{20}$ al-Ṭabāṭabāī, al-Mīzān fì Tafsīr al-Qurān, jil. 1, 134. berbagai kenikmatan yang dianugerahkan-Nya kepada manusia. Namun akan menjadi luar biasa manakala Allah masih juga menerima taubat hamba yang telah melakukan dosa, padahal sebelumnya nikmat Allah telah dicurahkan kepadanya. Ini adalah bukti keMahaPengasihan Allah yang lebih luas lagi. 'Allāmah al-Ṭabāțabā'̄ bahkan menjelaskan dalam konteks ayat ini kata 'menerima' (talaqqā) memiliki makna mengajarkan, yakni menerima perkataan dengan pemahaman (fahm) dan pengertian yang mendalam (figh), sehingga penerimaan inilah yang menjadi jalan pembersihan Nabi Adam dari segala kesalahannya. ${ }^{20}$ Lebih lanjut, mengenai taubat ini 'Allāmah al-Ṭabāṭabā'̄̄ memberikan pelajaran penting bahwasanya:

"Taubat ini adalah yang menghadirkan pensyariatan jalan yang menuntut penempuhnya dan membersihkan yang telah diturunkan (Nabi Adam) yang masih mengharapkan kediamannya (surga). Maka di baliknya ada pensyariatan agama dan penegakan millah.

Ini sesuai dengan yang berulangkali Allah sampaikan dalam firman-Nya dengan mendahu-lukan taubat atas iman. Firman Ta ālā: 'Maka tetaplah kamu pada jalan yang benar, sebagai-mana diperintahkan kepadamu dan (juga) orang yang telah taubat beserta kamu..' (11:112) dan firman-Nya: 'Dan sesungguhnya Aku Maha Pengampun bagi orang yang bertaubat, beriman,..' (20:82), dan ayat lain sejenisnya." 21

Dari penjelasan 'Allāmah al-Ṭabātabā'̄̄ ini jelaslah walaupun manusia telah melakukan dosa, tetapi Allah masih membuka kesempatan bagi manusia untuk kembali ke kampong 134.
${ }^{21}$ al-Ṭabāṭabāì, al-Mīzān fì Tafsìr al-Qurān, jil. 1, 
halaman sejatinya, yakni surga. Kesempatan ini berlaku bagi seluruh manusia dengan Adam sebagai representasi dalam ayat ini. Pintu taubat terus terbuka salah satunya dengan pensyariatan agama dan penegakan millah. Untuk inipun Allah masih juga memberikan rahmat-Nya kepada manusia berupa pengajaran dan pengertian yang men-dalam bagi mereka yang akan menempuh jalan taubat ini. Dari sini tampaklah sedemikian melimpahnya kasih sayang Allah kepada manusia.

\section{c. Kesaksian Primordial Meniscayakan Penghambaan}

Mengenai kesaksian primordial manusia dalam QS. al-A rāf: 172, ‘Allāmah alTabātabā'̄ menafsirkan bahwasanya ayat ini bersamaan dengan dua ayat setelahnya yang menjelaskan perjanjian Bani Adam berkenaan dengan ketuhanan. Menurutnya ayat ini di antara yang paling halus berkenaan dengan topik ini, selain itu juga paling elegan tetapi ekspresif. Setelah “..mengeluarkan keturunan anak-anak Adam dari sulbi mereka..” maka Allah “..mengambil kesaksian terhadap jiwa mereka...”. Kesaksian dimaksud adalah, "Bukankah aku ini Tuhanmu?" Dan dijawab dengan kesaksian bahwa mereka menyaksikan realitas yang ditanyakan kepada mereka dengan afirmasi, "Betul (Engkau Tuhan kami), kami menjadi saksi." Tujuan dari kesaksian ini adalah agar mereka menyaksikan ketuhananNya, sehingga mereka menyaksikan dan mengakuinya kapanpun hal ini ditanyakan kepada mereka tanpa ada alasan lain selain itu. ${ }^{22}$

Berkenaan dengan pengabdian ini, rasanya perlu pula untuk memperhatikan

22 al-Ṭabāṭabāī, al-Mīzān fì Tafsīr al-Qurān, jil. 8 hal. 311-312. secara langsung tafsir `Allāmah al-Ṭabāțabā'̄', "Dan aku tidak menciptakan jin dan manusia melainkan supaya mereka menyembah-Ku”, (51:56). 'Allāmah al-Ṭabāṭabā'̄i menjelaskan bahwasanya ayat ini disampaikan setelah Allah menyampaikan beberapa tindakan-Nya untuk manusia, yakni penciptaan, pengutusan para rasul, menurunkan azab yang semuanya menggunakan perantara seperti malaikat dan kausalitas dengan berbagai tujuan. Tetapi berbeda dengan ayat ini yang menjadikannya khusus hanya Allah (mā khalaqtu) tanpa ada satu sekutupun. Penyebutan jin sebelum manusia (al-jin wa al-insān) dikarenakan penciptaan jin lebih dahulu dari manusia. Adapun "melainkan agar mereka beribadah" (illā liya 'budūn) adalah pengecualian untuk menegaskan tidak ada keraguan bahwa kemunculan jin dan manusia dalam penciptaan memiliki tujuan, yakni ibadah dalam makna mereka semestinya menjadi para hamba bagi Allah bukan menjadikan-Nya sekedar sesembahan. Hal ini dikarenakan redaksi kalimat yang digunakan adalah "agar mereka beribadah" (liya budūn) bukan "agar mereka menjadikan sesembahan bagi mereka" (liakūna ma`būdan lahum). ${ }^{23}$ Sedangkan hakikat dari ibadah:

"Maka hakikat ibadah adalah sang hamba menempatkan dirinya dalam maqam kehinaan, penghambaan, dan mengarahkan wajahnya kepada maqam Tuhannya. Inilah yang diinginkan dari menafsirkan ibadah dengan ma`rifah, yakni ma`rifah yang dihasilkan dari ibadah.

Hakikat dari ibadah adalah tujuan tertinggi dari penciptaan yang memutus sang hamba dari dirinya dan dari setiap sesuatu demi mengingat Tuhannya."24 389-391

${ }^{23}$ al-Ṭabāṭabāī, al-Mīzān fì Tafsìr al-Qurān, jil. 18,

${ }^{24}$ al-Ṭabāṭabāī, al-Mīzān fì Tafsīr al-Qurān, 392. 
'Allāmah al-Ṭabātabā'ī menutup tafsir ayat ini dengan menyatakan ayat ini juga bermakna tidak akan ada pertolongan Allah bagi mereka yang tidak beribadah kepada-Nya, sebagaimana dinyatakan dalam sebuah ayat, "Katakanlah (kepada orang-orang musyrik): Tuhanku tidak mengindahkan kamu, melainkan kalau ada ibadatmu” (25:77).

\section{d. Qadar}

'Allāmah al-Ṭabāṭabā'̄̄ menjelaskan bahwa-sanya al-qadar secara bahasa memiliki kedekatan makna dengan 'batasan' (alhadd). ${ }^{25}$ Dia meng-ilustrasikannya dengan seorang arsitek yang membuat bangunan. Dalam merancang suatu bangunan, tentu seorang arsitek memiliki ukuran dan batasan atas setiap sendi bangunan yang akan dibuatnya sejak dari pondasi hingga atap. Berdasarkan batasan dan ukuran yang dibuat dalam rancangan itulah maka suatu bangunan kemudian dibuat. Dalam penciptaan, setelah Allah menentukan sesuatu maka segala sesuatu itu kemudian berjalan sesuai dengan ketentuan yang telah ditentukan tersebut, misalnya dengan hukum alam. Setiap fenomena dalam kosmos adalah suatu hal yang niscaya terjadi dan tidak akan menyalahi ketentuan yang telah ditentukan sebelumnya dan tidak akan menyimpang dari batasannya.

Menurutnya ini sesuai dengan firman Allah, "Dan tidak ada sesuatupun melainkan pada sisi Kamilah khazanahnya; dan Kami tidak menurunkan melainkan dengan ukuran yang tertentu" (15:21). ${ }^{26}$ Konteks ayat ini berkenaan dengan rezeki yang Allah anugerahkan kepada manusia dan hewan

${ }^{25}$ al-Ṭabāṭabāī, al-Mīzān fì Tafsīr al-Qurān, jil. 12, 139.

26 Al- 'Allāmah al-Sayyid Muḥammad Husayn alṬabāțabāī, Islam Syiah: Asal-Usul dan Perkembangannya (Jakarta: Grafiti Pers, 1989), 151. sehingga dapat melang-sungkan kehidupannya berupa tumbuhan dalam ungkapan "syay'in" yang turut membawa serta biji-bijian dan buah-buahan dalam ungkapan "khazāinuhu”. Dia menurunkan hujan dengan kadar (biqadarin) tertentu sehingga tumbuhtumbuhan itu dapat tumbuh dan mengalirkan manfaat kepada manusia dan hewan. ${ }^{27}$

'Allāmah al-Ṭabāṭabā'̄ menafsirkan bahwa, "Dan tidak ada sesuatupun..." (Wa in min syay'in...) adalah sebab umum sehingga menjadikan konteks pembicaraan sebagai penafian sekaligus penegasan dengan " $m i n$ ". Setiap yang dirujuk dengannya adalah sesuatu (syay') tanpa hal lain selain yang dirujuk tersebut kecuali yang ditujukan oleh konteks, yakni lafaz "kami” (nā), "sisi” ( inda), "khazanah-khazanah" (khazāin), dan apapun selain itu yang ia lihat yang tanpanya sesuatu tersebut secara umum tidak utuh. Adapun “..dan Kami tidak menurunkannya melainkan dengan ukuran yang tertentu” (..wa mā nunazziluhu illā biqadarin ma 'lūmin), yakni mengiringkan penciptaan dengan ukuran (biqadarin) waktu dan tempat selazimnya. Huruf " $b a$ " dalam frase ini bisa sebagai penyebab, instrumen, pembantu, atau satu konsekuensi yang karenanya sesuatu itu bertambah menjadi sesuatu lain dan kemunculannya merupakan konsekuensi dari “ukuran yang tertentu” (al-qadar al-ma 'lüm) sehingga wujudnya dibatasi dengan pasti. Lebih lanjut, ia menafsirkan bahwasanya 'ukuran' (qadar) dalam ayat ini adalah yang menjadi sebab sesuatu terjadi dan memerikan dari selainnya. ${ }^{28}$

\footnotetext{
${ }^{27}$ al-Ṭabāṭabāī, Islam Syiah, 151.

28 al-Ṭabāṭabāī, Islam Syiah, 141-142.
} 
Dalam kaitannya dengan kehendak bebas manusia, 'Allāmah al-Ṭabāṭabā'̄ mengafirmasi dengan menyatakan bahwasanya sebagai bagian dari kosmos, secara ontologis manusia memiliki hubungan dengan bagian lain dari kosmos. Setiap bagian memiliki pengaruh terhadap bagian yang lain. Sehingga dalam realiasi dari ikhtiar yang dilakukan oleh manusia, ia tidak terlepas dari hukum kausalitas. Ketika komponen suatu sebab telah utuh, maka akibat akan muncul. Ikhtiar manusia adalah salah satu dari kelengkapan komponen sebab tersebut. Kausalitas itu sendiri secara ontologis adalah bagian dari qadha, sedangkan secara kosmologis adalah bagian dari qadar. Dengan kata lain, kausalitas pun tidak luput dari kuasa Allah.

“..manusia bebas (mukhtar) dalam perbuatan-perbuatannya tapi tidak mandiri (mustaqil). Sesungguhnya, Tuhan Maha Kuasa melalui kehendak bebas mengingini perbuatan itu. Sesuai dengan uraian kita terdahulu, Tuhan Yang Maha Mulia telah berkehendak dan mengharuskan perbuatan itu melalui semua bagian dari sebab-lengkap, yang salah satu darinya adalah kehendak dan pilihan bebas manusia. Sebagai akibat dari kehendak Ilahi semacam ini, perbuatan itu adalah harus dalam hubungannya dengan keseluruhan sebablengkap, dan adalah pilihan bebas dan mungkin dalam hubungannya dengan salah satu bagian dari sebab, yaitu manusia." ${ }^{29}$

\section{Titik Temu: Kritik Metodologi, Perhatian} terhadap al-Qur'an, dan Iman

Meskipun berasal dari dua tradisi keislaman yang berbeda, kedua tokoh ini memiliki banyak persamaan dalam latar belakang intelektual. Sejak dini, keduanya sama-sama dibesarkan dalam tradisi keilmuan Islam yang kuat, walaupun dalam perkembangan selanjutnya masing-masing menempuh jalan yang berbeda. Fazlur Rahman melanjutkan pendidikannya ke Dunia Barat dengan tujuan pokok untuk mempelajari metodologi penelitian akademis yang dianggapnya jauh lebih baik dari Pakistan dan Dunia Islam pada umumnya. Sementara 'Allāmah al-Ṭabātabā'̄̄ terus mendalami proses pendidikannya hingga ke jantung pendidikan Dunia Syìh-yakni Najaf dan Qum. Sekalipun demikian, 'Allāmah alTabāṭabā'̄̄ teruji dengan forum diskusi di Universitas Teheran di mana ia dipanel dengan seorang filsuf Perancis ternama saat itu, Henry Corbin. Keduanya juga memiliki perhatian intelektual yang sama terhadap al-Qur'an dan Filsafat, hingga masing-masing mencapai puncak intelektual dalam kedua bidang tersebut. Selain masing-masing memiliki sejumlah karya filosofis, dalam kajian al-Qur'an Fazlur Rahman menciptakan metode Hermeneu-tika tersendiri untuk memahami alQur'an sedangkan `Allāmah al-Ṭabāṭabā'̄ pun menyusun tafsirnya, berjudul al-Mīzān $f i$ Tafsìr al-Qurān.

Dalam pembahasan mengenai Tuhan, meski memiliki sejumlah perbedaan pandangan akan tetapi terdapat pula titik temu antara keduanya.

Pertama, sebelum menegaskan metodologi yang digunakan dalam tafsir, keduanya mem-berikan perhatian terhadap metodologi penafsiran yang telah ada sebelumnya. Keduanya berada pada titik kesimpulan yang sama, yakni mengkritik penafsiran partikular yang dihasilkan oleh intelektual muslim sebelumnya yang hanya terbatas pada cabang keilmuan yang mereka

\footnotetext{
${ }^{29}$ al-Ṭabāțabāī, Islam Syiah, 153.
} 
tekuni. Secara spesifik, masing-masing mengarahkan kritiknya terhadap kalangan mutakal-lim, fuqaha, ahli hadits, bahkan filsuf. Keduanya juga mengkritik penafsiran yang digunakan untuk menjustifikasi penemuan ilmiah kontemporer. Hal ini dapat dimaklumi karena jenis tafsir yang terakhir ini cukup marak pada saat itu bahkan hingga hari ini.

Kedua, dalam menafsirkan al-Qur'an keduanya lebih mendahulukan penafsiran Qurān bi al-Qurān. Keduanya meyakini bahwa ayat-ayat yang terdapat dalam alQur'an bisa digunakan untuk saling menjelaskan satu sama lain. Selain menunjukkan wawasan keduanya akan alQur'an, metode ini juga memiliki kelebihan karena diakui sebagai metode terbaik dalam menafsirkan al-Qur'an.

Ketiga, keduanya sangat memperhatikan perkembangan ilmu pengetahuan sehingga tak jarang untuk memberikan pemahaman yang lebih dalam terhadap suatu ayat, keduanya memberikan penjelasan tambahan dengan berbagai bidang ilmu pengetahuan lain. Dalam Hermeneutika Fazlur Rahman, peranan ilmuilmu sosial sangat kental. Dia memasukkannya ke dalam proses penafsiran sebagai bagian integral dari Hermeneutika yang dibangunnya. Sedangkan 'Allāmah al-Ṭabāṭabā'̄ memisahkannya secara tersendiri dan memerikannya dalam subjudul penjelasan berdasarkan bidang ilmu pengetahuan yang akan dielaborasinya.

Keempat, keduanya berpandangan bahwasanya untuk mengenal Tuhan, maka pertama kali yang semestinya dilakukan adalah membuka diri pada kemungkinan akan keberadaan Tuhan. Kemudian proses ini dilanjutkan dengan upaya mempelajari berbagai fenomena kosmos untuk mencari dan memahami keberadaan-Nya dari jejak penciptaan. Fazlur Rahman menyebut ini sebagai proses 'mencari' (find) dengan cara mengubah cara pandang terhadap realitas. Adapun 'Allāmah al-Ṭabāṭabā'̄ mendasarkannya pada fitrah dan insting kesadaran akan fenomena wujud yang kemudian ia sebut 'Cara Mengenal Tuhan Menurut al-Qur'an' atau secara filosofis disebut dengan 'realisme instingtif'.

\section{Menepis Tudingan dengan Konsepsi Ketuhanan Ontologis-Etis}

Dari elaborasi yang telah disampaikan mengenai konsepsi ketuhanan yang disampaikan oleh Fazlur Rahman menggunakan Hermeneutika Sintetis-Logis dengan evaluasi beradasarkan Tafsir al-Mīzān karya 'Allāmah al-Ṭabāțabā'̄', maka dapat ditarik beberapa landasan Ontologis-Etis yang dapat digunakan untuk menjernihkan kesalahpahaman mengenai konsepsi ketuhanan dalam Islam.

Pertama, bagaimanapun juga penjelasan filosofis penting digunakan sebagai pemicu bagi manusia untuk mengenal Tuhan. Penjelasan Fazlur Rahman mengenai Tuhan sangat mene-kankan sisi etis karena ia menganggap bahwa-sanya hakikat penjelasan al-Qur'an mengenai hal ini bukan untuk tujuan spekulasi-teologis. Baginya sifat penjelasan alQur'an mengenai hal ini hanyalah untuk memandu manusia dalam 'menemui'-Nya. Akan tetapi, pada prakteknya kebutuhan akan penjelasan sarat teologis-filosofis justru diperlukan di awal perjalanan mengenal Tuhan guna menarik perhatian manusia untukdalam istilah Fazlur Rahman sendiri'menemui'-Nya. Di sinilah letak pentingnya berbagai metode pembuktian keberadaan Tuhan secara filosofis. Terkhusus dari 'Allāmah al-Ṭabātabā'̄̄, ia mengedepankan Burhān al-Ṣiddiqīn dengan rumusan yang dilandaskannya pada konsep fitrah dan 
kesadaran instingtif untuk menggerakkan manusia 'menemui'-Nya. Sampai di sini, kedua intelektual besar ini bertemu dalam perhatian besar terhadap al-Qur'an dan aspek kesadaran manusia.

Kedua, mengenai ke-TakTerhinggan Tuhan, penjelasan yang diberikan oleh 'Allāmah al-Ṭabāṭabā'̄̄ sangat radikal sehingga penting untuk diperhatikan. Perhatiannya terhadap aspek kebahasaan sedemikian detail, hal ini tampak pada penafsirannya atas QS. al-Kahf: 109. Tidak seperti kebanyakan mufassir, justru ia menafsirkan bahwa konstruksi kalimat dalam ayat tersebut bukan menekankan keTakTerhinggaan Allah melainkan betapa sangat jauh hingga tak layak untuk dibandingkan antara ke-TakTerhinggaan Allah dengan keterhinggaan manusia, bahkan untuk dibandingkan dengan satu makhluk ciptaanNya pun terlampau jauh. Dengan kata lain, fokus ayat berada pada topik pembicaraan bukan pada ke-TakTerhinggan-Nya. Penjelasan detail al-Qur'an seperti ini akan sangat bermanfaat dalam menggambarkan keter-gantungan antara yang terhingga kepada Yang Tak Terhingga.

Ketiga, ke-MahaPengampunan Allah atas dosa hamba adalah bukti paling kentara keMahaPengasihan Allah. Fazlur Rahman memberikan penjelasan mengenai berbagai nikmat yang telah dikaruniakan oleh Allah kepada manusia. Dia mengawalinya dengan menyampaikan QS. al-Naml: 60-64. Penjelasan seperti ini bisa digunakan sebagai awal penjelasan keMahaPengasihan Allah. Akan tetapi, penting untuk menjelaskan dengan detail bagaimana rahmat yang Allah berikan kepada mereka yang bertaubat, sebagaimana tafsir yang disampaikan oleh 'Allāmah al-Ṭabāțabā'̄̄ atas QS. al-Baqarah: 37. Ke-MahaPengasihan Allah akan sangat kentara dalam
pengampunan-Nya kepada hamba. Lebih lanjut, 'Allāmah al-Ṭabāṭabā'̄̄ mengaitkankannya dengan konsep pengajaran dan berujung pada risalah. Bahwa menunaikan syariat agama dan menegakkan millah adalah bagian dari cara manusia untuk mensyukuri kasih sayang yang telah Allah karuniakan. Apa yang disampaikan oleh kedua intelektual ini menjadi sangat relevan dengan kondisi saat ini guna menjernihkan makna syukur yang tidak bisa dilepaskan dari aspek pendidikan agar setiap hamba tidak buta dengan ajaran agamanya. Bahwasanya mendidik diri, memahami agama, dan berkomitmen atasnya adalah wujud konkret dari rasa syukur akan keMahaPengasihan-Nya.

Keempat, tujuan penciptaan adalah ibadah kepada-Nya. Allah pun telah mengambil kesak-sian manusia akan ketuhanan-Nya sebagaimana disampaikan dalam QS. al-A 'rāf: 172. Akan tetapi, manusia diberikan kebebasan dalam menjalankan kehidupannya di dunia, apakah akan menjalankan tujuan penciptaannya ini dengan baik atau tidak. Berkenaan dengan ini penjelasan ontologis mengenai qadar dari 'Allāmah al-Ṭabātabā'̄̄ saat menafsirkan QS. al-Hijr: 21 memiliki arti penting tersendiri karena mampu menjawab polemik dilematis mengenai kebebasan kehendak manusia dalam kaitannya dengan keMahaKehendakan-Nya. Penjelasan Moral-Etis dari Fazlur Rahman mampu mengimbangi secara praktis penjelasan 'Allāmah alTabātabā'̄i mengapa manusia harus berhatihati dalam memilih jalan kehidupannya dalam rangka mengantisipasi pertanggungjawaban di hadapan Allah kelak. Kesadaran utuh Ontologis-Etis ini menjadi penting seiring dengan gerak laju kehidupan manusia modern saat ini yang serba skeptis atas berbagai penjelasan agama yang dogmatis. 


\section{Simpulan}

Tudingan negatif terhadap konsepsi ketuhanan Islam bisa dijawab dengan sangat baik melalui penjelasan filosofis-teoritis, khususnya dari aspek ontologis dengan merujuknya langsung kepada al-Qur'an. Adapun penjelasan moraletis hanya bisa efektif manakala penjelasan ontologis telah dilakukan, guna me-ngantisipasi tudingan lanjutan bernada negatif karena kesalahpahaman atas konsepsi beragama muslim yang berusaha meniru akhlak Tuhan dalam laku kehidupan secara praktis.

Nama-nama dan sifat-sifat Allah saling terkait satu sama lain. Hal ini tampak dari konsep ke-TakTerhinggaan Khaliq atas keterhinggaan makhluk yang terkait erat dengan konsep ketergantungan makhluk terhadap Khaliq.

Ke-MahaPengasihan Allah tidak hanya tampak dari berbagai karunia-Nya untuk manusia, tapi juga dari sifat-Nya Yang Maha Pengampun, Maha Memberi Petunjuk, dan risalah Ilahi yang telah diwahyukan-Nya kepada para nabi dan rasul sebagi petunjuk bagi umat manusia.

Penghambaan kepada Allah tidak selayaknya dipandang negatif, seolah sama dengan penghambaan manusia kepada manusia. Dikarenakan penghambaan kepada Allah adalah tujuan primordial manusia sejak awal penciptaan.

Allah telah menentukan qadha' atas segala ciptaan-Nya yang direalisasikan melalui qadar-Nya. Segala sesuatu tidak terlepas dari qadar-Nya, termasuk manusia. Sekalipun demikian, manusia tetap memiliki kehendak bebas dalam menjalani kehidupannya di dunia apakah akan menunaikan tujuan primordialnya dengan baik atau tidak. Pastinya, segala pilihan itu akan dipertanggungjawabkan di hadapan Allah kelak.
Penting untuk mempertahankan keseimbangan antara aspek Filosofis-Teoritis dan Filosofis-Praktis dalam memberikan penjelasan akan ajaran Islam, karena yang pertama akan memberikan kekuatan dalam keyakinan beragama dan yang kedua akan memotivasi dalam melakukan berbagai kebaikan sebagai manifestasinya. Kedua aspek ini memiliki peran yang sangat penting di tengah kehidupan manusia modern yang serba skeptis dan senantiasa menuntut penjelasan logis dalam segala lini kehidupan.

\section{Pustaka Acuan}

Al-Khwānsārī, Muḥammad Taq̄̄ Anshāriyān. Ma 'rüf fì as-Samā' wa Kafa bi Dzalika Majadan: Dzikriyyāt wa Watsāiq Tansyir li Awwal Marrah Hawla Hayāh wa Sìrah al- 'Allāmah ar-Rāhil as-Sayyid Muhammad Husayn al-Ṭabātabā'ō. Qum: Muassasah Anshāriyān li alThibā'ah wa an-Nasyr, 2015.

Al-Ṭabāṭabā'̄̄, al- 'Allāmah al-Sayyid Muḥammad Husayn. Al-Mīzān fì Tafsīr al-Qurān. Beirut: Mansyūrāt Muassasah al-A'lāmī li al-Mathbū’āt, 1997.

-----. Islam Syiah: Asal-Usul dan Perkembangannya. Jakarta: Grafiti Pers, 1989.

Fahham, Achmad Muchaddam. Tuhan dalam Filsafat 'Allāmah Al-Tabātabā' Relevansi Pandangan Moral dengan Eksistensi Tuhan dalam Realisme Instingtif. Yogyakarta: Rausyan Fikr Institute, 2012.

https://www.theguardian.com/

Rahman, Fazlur. Islam \& Modernity: Transformation of an Intelectual Tradition. Chicago: The University of Chicago Press, 1982.

----. Major Themes of the Qur'an. Minneapolis-Chicago: Bibliotheca Islamica, 1994.

Shafā, 'Alī Jābir Āli. Nazhariyah al-Ma'rifah wa al-Idrākāt al-I tibāriyah `inda al- 
22 Ilmu Ushuluddin, Volume 6, Nomor 1, Januari 2019

'Allāmah ath-Al-Tabātabā ’̄. Beirut: Dār al-Hādī, 2001.

Sibawaihi. Hermeneutika Alquran Fazlur Rahman. Yogyakarta: Jalasutra, 2007

Syamruddin, "Hermeneutika Fazlur Rahman: Upaya Membangun Harmoni Teologi, Etika, dan Hukum", MIQOT, Vol. XXXV No. 2, 2011.

Tihrani, Sayyid Muḥammad Ḥusayn Husayni. Shining Sun: In Memory of 'Allamah Tabataba'i. London: ICAS Press, 2011. 